\title{
Implementation of Student - Team - Achievement - Divisions activity and Flipped classroom to enhance student learning
}

\author{
Javeed Kittur \\ Department of Electrical \& Electronics Engineering, \\ B.V.Bhoomaraddi College of Engineering \& Technology, Hubli - 580031 \\ javeed@bvb.edu
}

\begin{abstract}
The typical pattern of classroom interaction is the Initiation - Response - Evaluation (IRE) pattern which has been accountable for $70 \%$ of teacher - student classroom interactions. In this IRE approach, a teacher initiation (I) is followed by a student reply (R) and then an evaluation of this reply (E) by the teacher. IRE approach has been considered unrewarding and leads to boring classroom discussions. Also, there is an increasing need to provide students with learning experiences that reflect the challenges and opportunities of the $21^{\text {st }}$ century. One key class of workforce skills relates to Rapid Collaborative Knowledge Building (RCKB). RCKB techniques include problem identification, brainstorming, prioritizing, concept mapping, and action planning. With inclusion of these techniques in the classroom, students learn the existing subject more deeply and also to become active participants in $21 \mathrm{st}$ century. Keeping all these aspects in mind the Student Team - Achievement - Divisions (STAD) collaborative activity was planned and implemented. In traditional teaching approach a teacher in a classroom stands on the dais and delivers a lecture and writes on a black board. The teacher is aware that most students do not understood the lesson and the teacher is helpless as the class slot is just of one hour and there is a lot of material to cover before the test at the end of the unit. This traditional learning model will not encourage students who are accustomed to active learning, either on their own or in small groups of classmates. In order to address this issue flipped classroom was implemented. The work presented in this paper summarizes the effectiveness of
\end{abstract}

\section{Javeed Kittur}

Department of Electrical \& Electronics Engineering, B.V.Bhoomaraddi College of Engineering \& Technology, Hubli - 580031

javeed@bvb.edu collaborative activity and flipped classroom used in enhancing students' learning and performance in basic electrical engineering course.

Keywords: collaborative activity, enhanced learning, enhanced performance, flipped classroom, STAD

\section{Introduction}

In STAD (Slavin, 1994), students work in a team to four member mixed in performance level, sex and ethnicity. The teacher explains a concept, and the students work within teams to make sure that all team members have mastered the concept [1]. Later, all the students take up individual quiz related to the concept taught, during which the students will not help one another. Students' quiz scores are compared with their own past performance scores, and points are awarded for this quiz based on the degree to which students meet or exceed their own earlier performances. These individual points are then summed to form team performance scores, and teams that meet certain criteria earn rewards. The whole cycle of activities, right from teacher explanation to team discussions to quiz, usually requires three to five class periods. STAD collaborative activity is most appropriate for teaching objectives that are well - defined. In STAD, students work in 4 - member heterogeneous teams to help each other master academic content. Collaborative learning is a situation in which two or more people learn together, "two or more" represents a small group, "learn something" indicates "follow a course", "study course material", "perform learning activities such as problem solving", "learn from lifelong work practice", etc and "together" may be interpreted as different forms of interaction: face-to-face or computer-mediated, synchronous or not, frequent in time or not, whether it is a truly joint effort or whether the work is divided in a systematic way [2]. The major challenges in 
designing the collaborative activities are; (a) setting concise and effective objectives relating the course outcomes and (b) effective templates for monitoring progress, recording reflections and grading outcomes, challenges and achievements. The strategies for successful implementation of collaborative activities are; forming effective groups, help students develop team skills before starting collaborative work, what technologies might assist collaborative work, how to facilitate collaboration, how to deal with conflicts amongst team members. The effects of collaboration can be measured through pre-tests / post-tests, individual / group performances [3]. The response from the students' feedback showed that they were more satisfied with teaching through collaborative activity than the conventional chalk and talk method; it helped them to understand the concepts better. It also showed increased involvement in learning during the activity.

Students increasingly expect a classroom experience that helps them develop knowledge for them, not just passively receive one-dimensional information. Students want to do something meaningful with content instead of just listening to a lecture [4]. They also expect to meet with discussion groups and project teams and do much of their assigned work during class time instead of meeting separately. Another factor that is playing an important role in student perceptions: the value gained from education in a tough economy. Instructors need to make education worth a student's investment of time and money by ensuring the classroom experience is productive and meaningful. These expectations are leading higher education toward "flipped" classrooms and a learning model that blends online and inclass learning [5]. In a flipped model, students view the lecture material online before they arrive in the classroom, so they are ready to immediately discuss the topic or begin work on a related individual or small-group activity. This model uses multiple technologies for instruction. At the start of the class the students took a multiple choice quiz, to rate their understanding of the concepts which they had to study prior to the class. The rest of the class time was used to discuss and clarify the doubts and solve more problems. Students' feedback was taken and feedback showed that they were more satisfied with experiences of teaching through flipped classroom than the conventional chalk and talk method; it helped them to understand and remember the concepts. It also showed increased involvement in learning during the flipped classroom session. The flipped classroom is defined as an educational technique that consists of two parts: interactive group learning activities inside the classroom, and direct computer-based individual instruction outside the classroom [6].

\section{Methodology}

\section{A. Student - Team - Achievement - Division Activity}

The main objectives of this activity are better understanding of the concepts, revision of important concepts, gain mastery over the concepts, students will learn to work in teams, increase student's involvement in class and learn by helping the teammates. In order to achieve the set objectives and to implement the STAD activity, three class hours were utilized. Heterogeneous teams were formed with four students in each team. Prior to the class, the students were given the material which they had to go through before attending the class, so that the class time could be effectively utilized to summarize the reading, clarify doubts, discuss, revise the concepts and solve problems. This procedure was followed for the first two classes and in the third class a test was conducted to assess the students' learning and performance. Students' assessment was done through detailed rubrics to have fair evaluation. The implementation details of this activity are as follows:

\section{1) Team formation}

The teams were formed based on their previous semester's grade points, each team had four students.

- Student 1 has a score greater than 9.0 points,

- Student 2 has a score in the range $7.5-9.0$ points,

- Student 3 has a score in the range $6.0-7.5$ points,

- $\quad$ Student 4 has a score below 6.0 points.

One student in the team must be a girl (this condition is set because my class strength is 71 , one fourth of the class has female students and three fourth of the students are male). The rules and regulation about the activity and the intimation about the teams and the team members were done on the course website. The activity was also explained in class in brief.

\section{2) Class 1}

- Explanation on the DC motor construction in detail (15 minutes)

- Time was given to discuss among their teams so that they make sure that they have completely understood the motor construction (10 minutes)

- After their discussion time is over, if the students have any questions they can ask the instructor (5 minutes)

- Then the instructor will go ahead and explain the working principle of DC motor. (15 minutes)

- Again give them some time to discuss among their teams so that they make sure that they have completely understood the working principle (10 minutes)

- After their discussion time is over, if the students have any questions they can ask the instructor (5 minutes)

\section{3) Class 2}

- Explanation on the DC motor types (DC shunt motor and DC series motor) (15 minutes) 
- Time was given to discuss among their teams so that they make sure that they have completely understood the construction (10 minutes)

- After their discussion time is over, if the students have any questions they can ask the instructor (5 minutes)

- Then the instructor will go ahead and explain the characteristics of types of DC motor. (15 minutes)

- Time was given to discuss among their teams so that they make sure that they have completely understood the construction (10 minutes)

- After their discussion time is over, if the students have any questions they can ask the instructor (5 minutes)

\section{4) Class 3}

- All the teams were given some time to again discuss and revise all the concepts (15 minutes)

- A test was conducted which included multiple choice questions as well subjective question (30 minutes)

- After the test, time was spent to discuss the question paper (right answers for MCQ's and what answers should be written for subjective questions) (15 minutes)

The grading of the students for this activity was done as follows

- The class test was evaluated for 20 points.

- If a student scored more than or equal to his previous performance then he/she was given 20 points

- If the student's score was less than $10 \%$ to $20 \%$ of his previous performance then he/she was given 16 points

- If the student's score was less than $20 \%$ to $30 \%$ of his previous performance then he/she was given 14 points

- If the student's score was less than $30 \%$ to $40 \%$ of his previous performance then he/she was given 12 points

- If the student's score was less than $40 \%$ to $50 \%$ of his previous performance then he/she was given 10 points

- If the student's score was less than $50 \%$ of his previous performance then he/she was given 8 points

To find the team scores, the individual students' scores were summed and the team which scored the highest points was given an extra point as a bonus

\section{B. Flipped Classroom}

1) Classroom Flip Version:
- Prior to a class each student was asked to review lecture notes and related textbook reading.

- The students were also asked to complete an assignment having two subjective questions relating that topic of review.

- Class time was used for clearing students' doubts, think-pair-share activity, problem solving and feedback.

This version of classroom flip was successful from both student and instructor perspective, but there is room for improvement in several areas listed below

- Enhance student engagement during class

- Peer - assisted learning did not happen as expected because few students chose not to participate actively in the think-pair-share activity.

- While taking rounds in the class few students were not actively working on problems.

The authors wish to make the following modifications in the flipped classroom implementation in the coming semester.

- $\quad$ The text - based lecture notes will be replaced by recorded micro lectures of $10-15$ minutes in length and focused on specific objectives.

- Two to three micro lectures can be assigned for a class.

- $\quad$ Students will be asked to take up a test which will assess their individual readiness on the foundational knowledge before the class.

The following table summarizes the redesign of goals and teaching strategies.

Table 1. Redesign of goals and teaching strategies

\begin{tabular}{|l|l|}
\hline Goals for Redesign & \multicolumn{1}{|c|}{ Teaching Strategies } \\
\hline $\begin{array}{l}\text { Increase student } \\
\text { engagement and } \\
\text { learning during class }\end{array}$ & $\begin{array}{l}\text { Use structure team - based } \\
\text { learning rather than informal } \\
\text { cooperative learning pairs }\end{array}$ \\
\hline $\begin{array}{l}\text { Increase time on task } \\
\text { in the course as a } \\
\text { whole }\end{array}$ & $\begin{array}{l}\text { Attempt to make the outside-of- } \\
\text { class lectures more engaging and } \\
\text { effective by replacing text with } \\
\text { multimedia and including worked } \\
\text { examples of simple problems }\end{array}$ \\
\hline $\begin{array}{l}\text { Include lifelong } \\
\text { learning as an } \\
\text { explicit course goal }\end{array}$ & $\begin{array}{l}\text { Emphasized significant } \\
\text { responsibility for self-led learning } \\
\text { outside of class and team-based } \\
\text { learning inside of class }\end{array}$ \\
\hline
\end{tabular}

\section{Results and Discussion}

A. Student - Team - Achievement - Division Activity 
The topics that were covered during the conduction of this activity were DC Motor construction, DC motor working principle, DC motor types and Characteristics of DC shunt \& series motors. Table 2 shows the details of performance scores of each team and the probable reasons for the performance scores of each team.

Table 2: Team Performance Scores and the probable reasons for their performance

\begin{tabular}{|c|c|c|c|}
\hline $\begin{array}{l}\text { Team } \\
\text { No. }\end{array}$ & $\begin{array}{c}\text { No. of } \\
\text { students }\end{array}$ & $\begin{array}{l}\text { Team } \\
\text { Score }\end{array}$ & $\begin{array}{c}\text { Reasons for team's } \\
\text { performance }\end{array}$ \\
\hline 1 & 4 & 17 & $\begin{array}{l}\text { Good coordination in the } \\
\text { team }+ \text { involvement }\end{array}$ \\
\hline 2 & 4 & 18 & $\begin{array}{l}\text { Better understanding of } \\
\text { concepts }+ \text { bonus point }\end{array}$ \\
\hline 3 & 4 & 15 & $\begin{array}{l}\text { Good involvement }+ \text { minor } \\
\text { coordination problem }\end{array}$ \\
\hline 4 & 4 & 10 & $\begin{array}{l}\text { Lack of communication }+ \\
\text { limited interest }+ \text { two } \\
\text { students remained absent }\end{array}$ \\
\hline 5 & 4 & 16 & $\begin{array}{l}\text { Interest in the subject }+ \\
\text { involvement }\end{array}$ \\
\hline 6 & 4 & 12 & Improper coordination \\
\hline 7 & 4 & 16 & $\begin{array}{l}\text { Good coordination in the } \\
\text { team }\end{array}$ \\
\hline 8 & 4 & 15 & $\begin{array}{l}\text { Learning by helping } \\
\text { teammates }\end{array}$ \\
\hline 9 & 4 & 13 & $\begin{array}{l}\text { Disinterest of few members } \\
\text { of a team + care not attitude }\end{array}$ \\
\hline 10 & 4 & 18 & $\begin{array}{l}\text { Good at understanding and } \\
\text { taking lead roles }\end{array}$ \\
\hline 11 & 4 & 15 & $\begin{array}{l}\text { Good involvement in the } \\
\text { class }\end{array}$ \\
\hline 12 & 4 & 11 & $\begin{array}{l}\text { Weak communication }+ \text { less } \\
\text { involvement }\end{array}$ \\
\hline 13 & 4 & 13 & $\begin{array}{l}\text { Coordination problem }+ \\
\text { limited concept } \\
\text { understanding }\end{array}$ \\
\hline 14 & 4 & 15 & $\begin{array}{l}\text { Learning by helping the } \\
\text { teammates }\end{array}$ \\
\hline 15 & 4 & 11 & $\begin{array}{l}\text { Lack of interest }+ \text { slowing } \\
\text { learning }\end{array}$ \\
\hline 16 & 4 & 17 & $\begin{array}{l}\text { Hardworking + Good } \\
\text { understanding of the } \\
\text { concepts + one student } \\
\text { remained absent }\end{array}$ \\
\hline 17 & 3 & 12 & Team coordination problem \\
\hline 18 & 3 & 16 & $\begin{array}{l}\text { Good coordination in the } \\
\text { team }\end{array}$ \\
\hline
\end{tabular}

Fig. 1 shows the response to the question "Rate your learning through collaborative learning activity conducted in class" and from this figure it is clear that most of the students say that the learning is much higher than the conventional chalk and talk method. Also the average performance scores of minor exam two are higher than the average performance scores of the class as shown in Fig. 2.

The potential challenging areas that were encountered while conducting this activity were; to maintain the objective of the activity, maintaining the time limit for each bit (60 minutes time of the class that I have divided in four bits), controlling the class environment, keeping students involved in the class and team work (some groups may have students who do not like to discuss or talk to their team mates). Fig 3, shows the grades obtained by students in 2014 and 2015 . From this figure it is seen that the number of students who have scored grade A has increased in 2015 when compared with 2014.

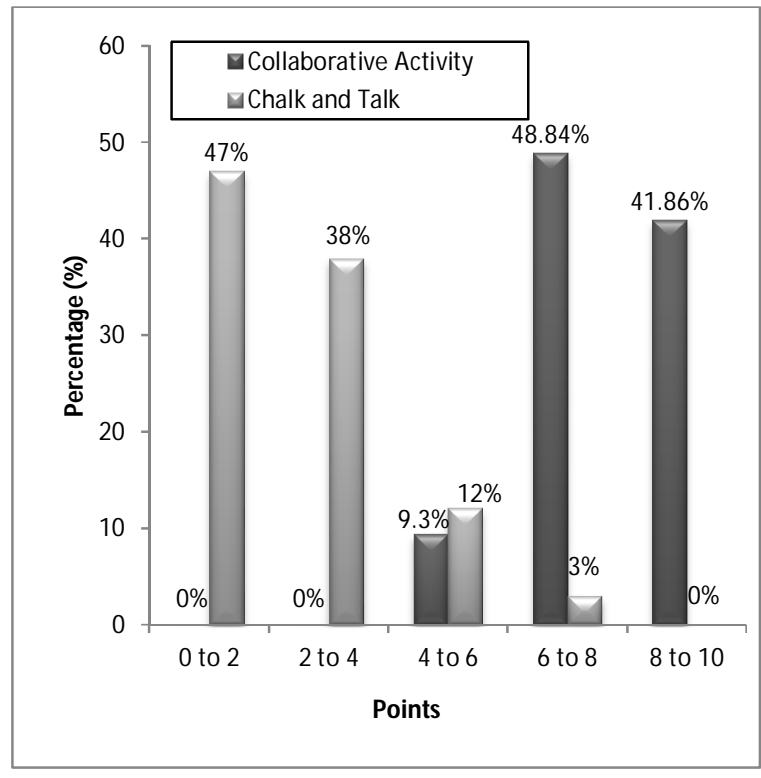

Fig. 1: Response to the question "Rate your learning through collaborative learning activity conducted in class"

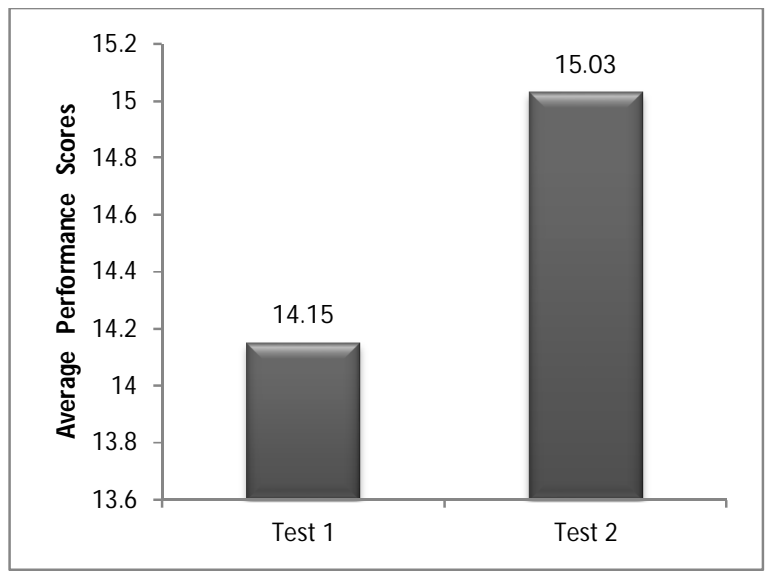

Fig. 2: Average Performance Scores of the class for Test 1 and Test 2 


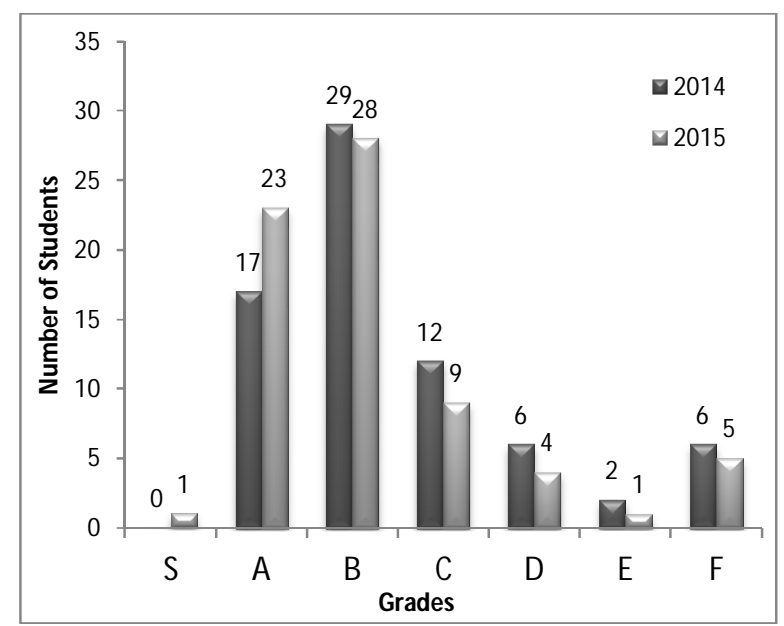

Fig. 3: Grades obtained by students in 2014 and 2015

\section{B. Flipped Classroom}

Fig. 4 shows the response to the question "Rate your learning through flipped classroom activity" and from this figure it is clear that most of the students say that the learning is higher than the conventional chalk and talk method.

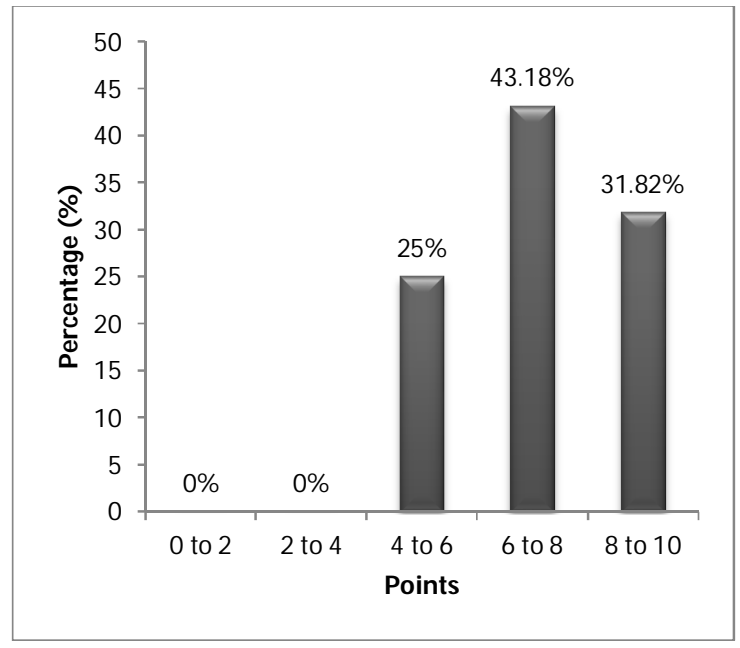

Fig. 4: Response to the question "Rate your learning through flipped classroom activity"

\section{Conclusions}

This paper describes the implementation of student - team achievement - division activity and flipped classroom in the course titled basic electrical engineering. The main aim of this paper was to enhance student learning and hence their performance. The STAD activity has motivated and encouraged the students to learn better. Flipped classroom was implemented to utilize the class hours effectively by spending more time on discussing students' doubts and solving more problems. From the test performance scores and the student feedback, it is found that implementation of the STAD activity and flipped classroom has enhanced student learning.

\section{Acknowledgement}

The author of this paper would like to thank the Principal, B.V.Bhoomaraddi College of Engineering \& Technology, Hubli and Head of department, Electrical \& Electronics Engineering, for providing with all facilities and support for carrying out the activities related to this work.

\section{References}

[1] Larry K. Michaelsen, "Professional and Organizational Development Network Essay Series Teaching Excellence: Toward the Best in the Academy", Vol. 9, 1997-1998

[2] Dillenbourg P, "What do you mean by collaborative learning? Collaborative-learning: Cognitive and Computational Approaches", pp.1-19, 1999

[3] Gul Nazir Khan, Hafiz Muhammad Inamullah, "Effect of Student's Team Achievement Division (STAD) on Academic Achievement of Students", Asian Social Science Vol. 7, No. 12; December 2011

[4] Jacob Lowell Bishop, Matthew A Verleger, "The Flipped Classroom: A Survey of the Research", 120 ${ }^{\text {th }}$ ASEE Annual Conference \& Exposition, June 23 - 26, 2013

[5] Clyde Freeman Herreid and Nancy A. Schiller, "Case Studies and the Flipped Classroom", Journal of College Science Teaching, Vol. 42, No. 5, 2013

[6] Rozinah Jamaludin, Siti Zuraidah Md Osman, “The Use of a Flipped Classroom to Enhance Engagement and Promote Active Learning", Journal of Education and Practice, Vol.5, No.2, 2014 